\title{
The University Medical Centre: A student's perspective
}

Gabrielle Hubert ${ }^{1}$, Cameron Pow ${ }^{2}$, Sandra Tullio-Pow ${ }^{1}$

${ }^{1}$ School of Fashion, Ryerson University ${ }^{2}$ Life Sciences, Queen's Univeristy

\section{Context}

Over 515,000 students attended Ontario Universities in 2015/16, including 60,000 international students from abroad (https://ontario universityes.ca/resources/data/ numbers). First-year students who are away from home find themselves needing a new primary care physician. While a few researchers have examined student health care within the university setting in regard to mental health (Evans, 1999), sexual health (Habel et al., 2018)., and health promotion (Griebler et al., 2017), there has been little research focused on the first-year student experience in finding primary care. Our study examined communication pathways, wayfinding and misconceptions students have related to the university medical centre.

Patient centered care involves a partnership between a healthcare provider and their patient. In this partnership healthcare professionals must consider the patient experience and be more informative, mindful, empathic and collaborative to provide the best possible care (Epstein \& Street, 2011).

\section{(9)0}

Figure 1. The

\section{Methods}

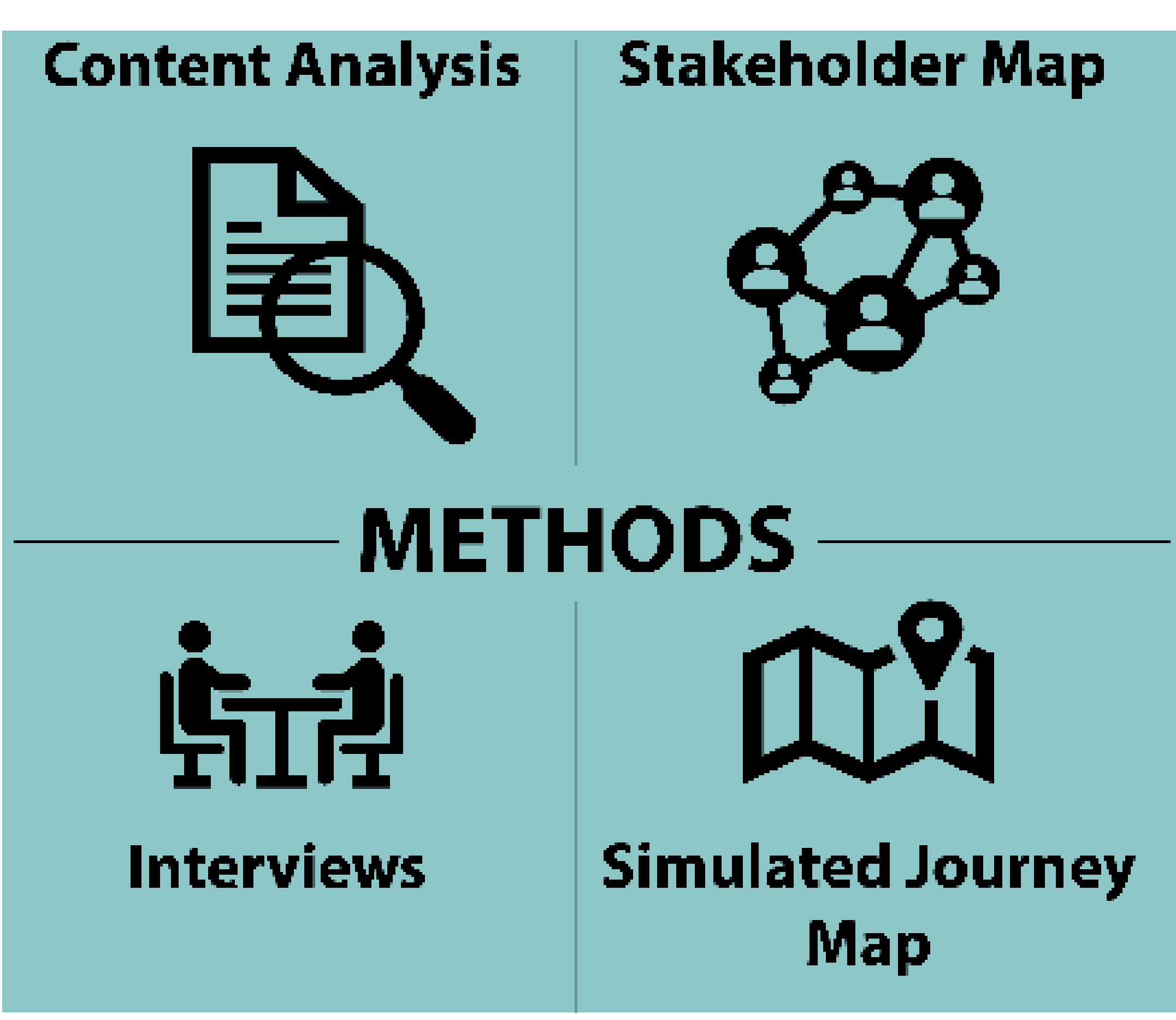

Figure 2. The methods used in the study

We began our investigation using a qualitative approach to examine how information about the Medical Centre is communicated to students (See Figure 2). Our content analysis (Hanington \& Martin, 2012, p. 40) included a review of websites, social media, student guides, signage and posters.

Following this we created a stakeholder map (Hanington \& Martin, 2012, p. 166) to identify people that interact directly with first-year students as they represent potential interview participants.

The simulated journey map (Hanington \& Martin, 2012, p. 196) created by the researchers determined the possible steps a first-year student might follow in order to see a physician to determine key issues and solutions.

Semi-structured interviews (Creswell, 2009, p. 179) were conducted with three staff members of the Medical Centre. Typical student visits were described. Questions focused on determining common student misconceptions and suggestions to improve communication.

WEBSITES SOCIAL MEDIA STUDENT GUIDES SIGNAGE \&
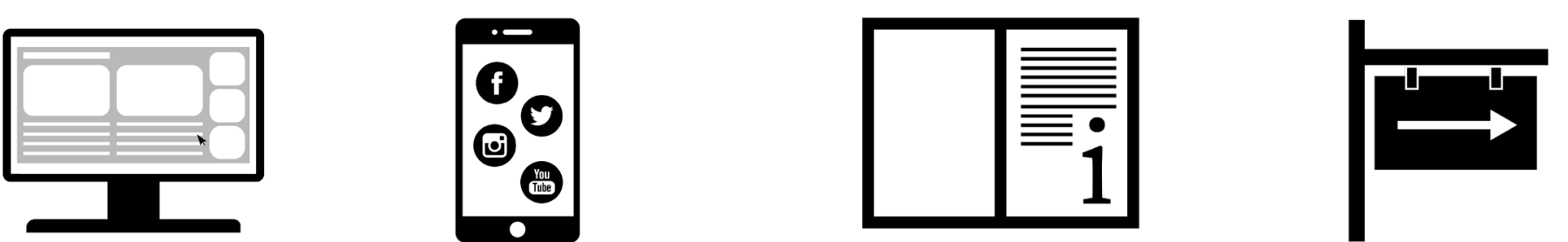

曲地

\section{Results}

\section{Content analysis}

The content analysis allowed us to identify communication points on the Medical Centre's website. We noted that directions to find the Medical Centre were insufficient. Other communication touch points including social media, student guides, and posters did not provide sufficient information about the Medical Centre, as illustrated in Figure 4. Finally, information provided during special events like orientation did not mention the Medical Centre.

\begin{tabular}{|c|c|c|}
\hline Category & Information & Directions \\
\hline \multicolumn{3}{|l|}{ Websites } \\
\hline Medical Centre & $\begin{array}{l}\text { Appointments } \\
\text { Mission statement and staff } \\
\text { Policies } \\
\text { Health insurance } \\
\text { Lab and test results } \\
\text { Emergencies } \\
\text { Links for other websites } \\
\text { Operating hours and phone } \\
\text { number }\end{array}$ & $\begin{array}{l}\text { Room number and } \\
\text { building } \\
\text { Address of the university }\end{array}$ \\
\hline University, Student Life & $\begin{array}{l}\text { Mention the Medical Centre } \\
\text { and provide a link to the } \\
\text { website }\end{array}$ & No directions \\
\hline Residence & Mention the Medical Centre & No directions \\
\hline Student Union & $\begin{array}{l}\text { No mention of the Medical } \\
\text { Centre }\end{array}$ & No directions \\
\hline \multicolumn{3}{|l|}{ Social Media } \\
\hline Twitter, Facebook & $\begin{array}{l}\text { Information about the Medical } \\
\text { Centre (how to book an } \\
\text { appointment) and provide a } \\
\text { link to the website }\end{array}$ & No directions \\
\hline Instagram & $\begin{array}{l}\text { No mention of the Medical } \\
\text { Centre }\end{array}$ & No directions \\
\hline YouTube & $\begin{array}{l}\text { One video (out of 462) } \\
\text { about the Medical Center } \\
\text { (information about the } \\
\text { medical services) }\end{array}$ & $\begin{array}{l}\text { Room number and } \\
\text { building } \\
\text { Easiest access by a } \\
\text { specific entrance }\end{array}$ \\
\hline \multicolumn{3}{|l|}{ Stude } \\
\hline $\begin{array}{l}\text { University (Resources } \\
\text { page) }\end{array}$ & $\begin{array}{l}\text { Information about the Medical } \\
\text { Centre (who it is for, services } \\
\text { provided, appointments) and } \\
\text { provide a link to the website }\end{array}$ & No directions \\
\hline One school (out of nine) & $\begin{array}{l}\text { Information about the Medical } \\
\text { Centre (services, phone } \\
\text { number) and provide a link to } \\
\text { the website }\end{array}$ & $\begin{array}{l}\text { Room number and } \\
\text { building }\end{array}$ \\
\hline $\begin{array}{l}\text { Two schools (out of } \\
\text { nine) }\end{array}$ & $\begin{array}{l}\text { Information about the Medical } \\
\text { Centre (services) and provide a } \\
\text { link to the website }\end{array}$ & No directions \\
\hline $\begin{array}{l}\text { Signage \& Posters } \\
\text { Informative posters }\end{array}$ & $\begin{array}{l}\text { Health promotion and } \\
\text { resources }\end{array}$ & No directions \\
\hline \multicolumn{3}{|l|}{ Events } \\
\hline $\begin{array}{l}\text { University events } \\
\text { website, Facebook }\end{array}$ & $\begin{array}{l}\text { No mention of the Medical } \\
\text { Centre }\end{array}$ & No directions \\
\hline
\end{tabular}

Figure 4. The main findings from the content analysis

\section{Stakeholder Map}

The stakeholder map confirms that there are many people involved in communicating information about the Medical Centre to students. This research took place during the summer, although we were able to interview administrative staff at the medical centre, we did not have access to students, and this is a limitation in this study.

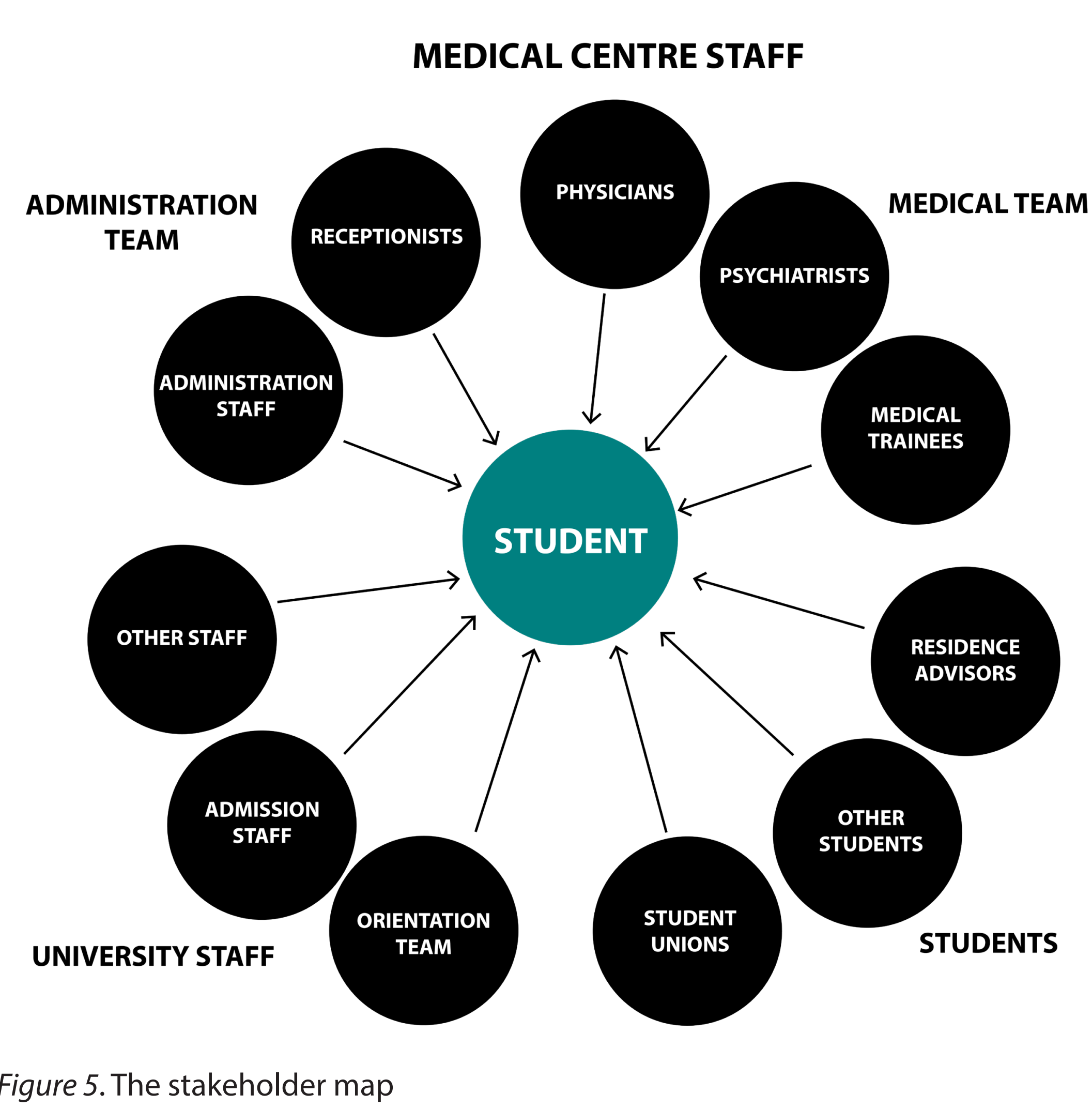

Simulated Journey Map

The journey map highlighted key issues in the process of booking an appointment at the Medical Centre. These included knowing about the Medical Centre when they are ill and finding the centre on campus. Signage and wayfinding were insufficient. Arriving without an appointment, their student card and health card was also problematic.
Interviews $(n=3)$

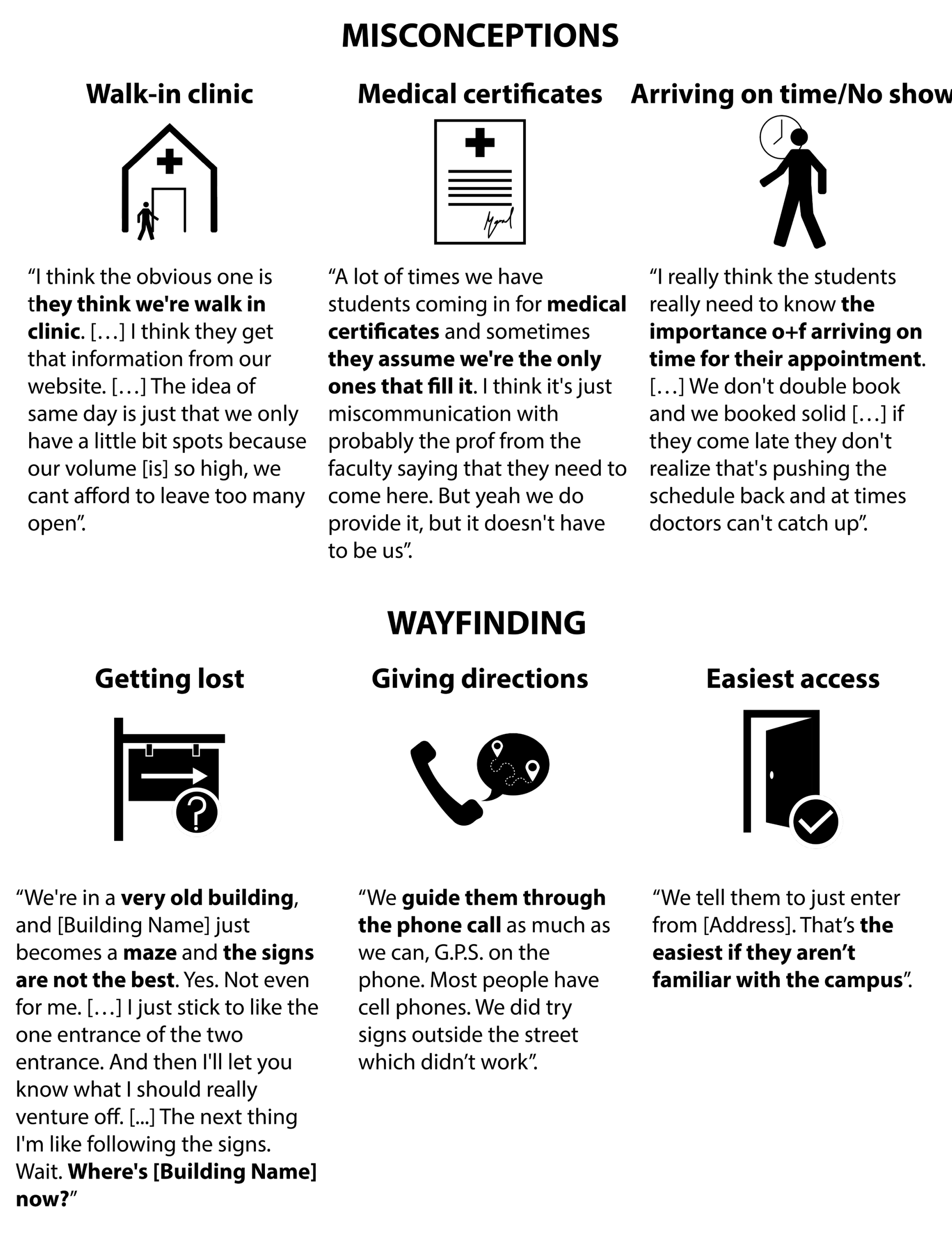

\section{Recommendations}

Suggestions from the Medical Centre's staff

. Put posters about the Medical Centre in residences to target first-years

2. Continue stations for health promotion during orientation week

3. Target first-years students as well as out-of-province and international students

4. Link information emails from University Admissions to include a link to the Medical Centre website

5. Emphasize the importance of arriving on time, providing $24 \mathrm{~h}$ notice if unable to keep their appointment and the serious implications of no-shows

6. Recommend that students call for an appointment rather than email

\section{Authors' recommendations}

1. Add more directions (map, easiest access) on the Medical Centre Website

. Encourage the university's other websites to include the location of the Medical Centre and a link to the website Create more informational content for social media

4. Create a template of information to send to all faculties and schools to include in their student guides

. Add more wayfinding signs in the building where the Medical Centre is located

. Paint the door to the medical centre with a coloured boarder around the door for further emphasis.

\section{Conclusion}

From a patient centered perspective, analyzing a first-year student's path to primary care led to recommendations for improvement related to wayfinding and communication pathways. Pain points along the patient journey were found through a content analysis of communication touch points, a simulated journey map, and interviews with medical center staff. Limitations of this study included the non-inclusion of the opinion of students and of other stakeholder groups identified. Further research would benefit from the inclusion of multiple stakeholder groups, particularly interviews or focus groups with students and residence staff to gather more holistic viewpoints.

\section{References}

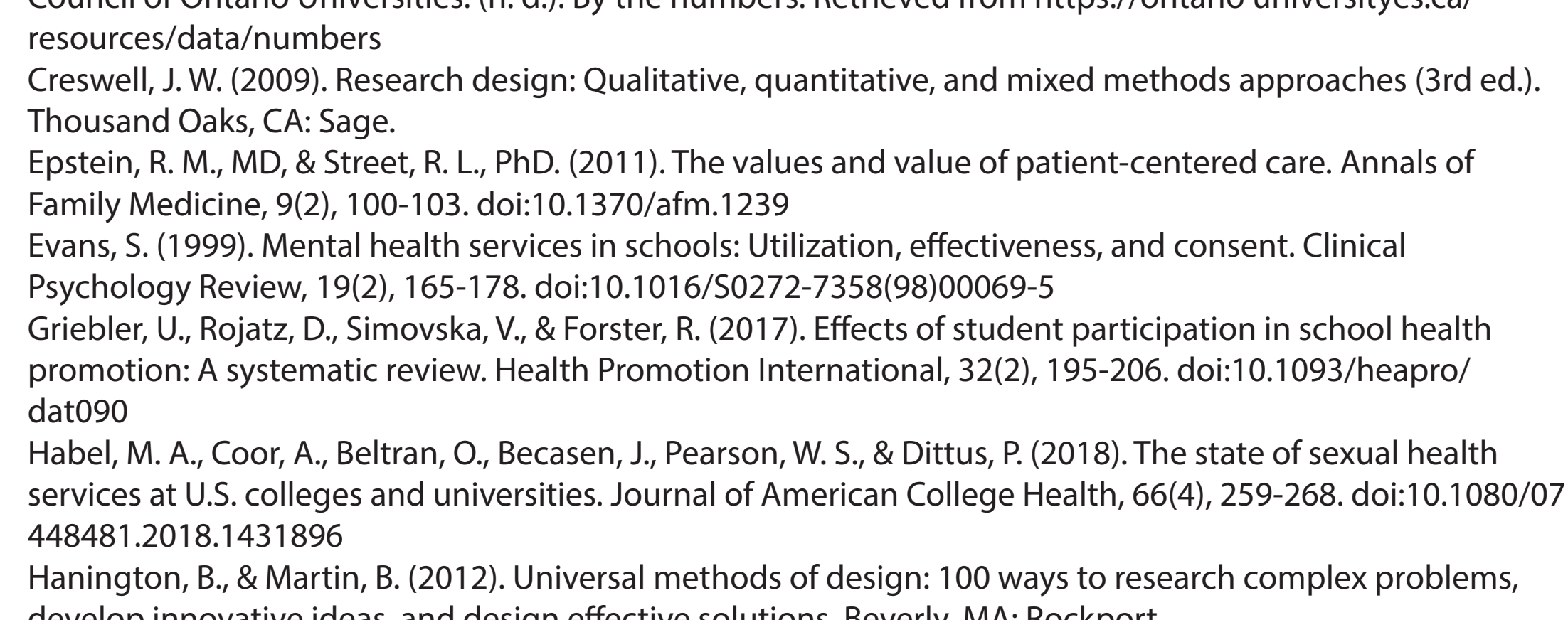

